Papers and Proceedings of the Royal Society of Tasmania, Vol.109, 1975

(ms. received 20.1.1975)

\title{
RECENT WHALE STRANDINGS IN NORTHERN TASMANIA
}

by E.O.G. Scott and R.H. Green

(with three tables and two plates)

\section{ABSTRACT}

Three strandings of whales have recently occurred on the north coast of Tasmania. They involve a single pilot whale, Globicephaza sp., amd two large schools of the false killer whale, Pseudorca crassidens.

\section{INTRODUCTION}

A stranding of a pilot whale (GZobicephaza sp.) was reported on 9.5.1973, and upon inspection by one of us (R.H.G.) the animal was found to be stranded head seawards at the high tide mark on rocks at the northern end of Greens Beach, northern Tasmania (plate 1). It was fresh and appeared to have died within the previous few days. The colour was uniform black. The dentition was $\frac{9}{7} \frac{9}{7}$ A series of measurements is given in table 1 .

Upon dissection the uterus appeared empty, and the stomach contained only a sma11 quantity of white seaweed-1ike material. The head was removed for subsequent preparation of the skull, and within the nasal cavity there was found a considerable number of nematodes, later determined as Stenums sp., probably S. globicephalae Baylis and Daubney, 1925. Specimens of the dolphin Lagenorhynchas acutus Gray, 1828 stranded on the coast of Massachusetts, U.S.A., in May 1973 were studied by members of the staff of the New England Aquarium in an endeavour to determine a possible cause of the stranding. It was discovered the nasal cavity and the inner ear of these animals were infested with S. gzobicephazae (pers. com. Louis Garibaldi).

No barnacles or other ectoparasites were observed in our specimen.

If the view of Van Bree (1971) that within the genus Globicephala Lesson, 1828 only two species can be recognised, $G$. melaena (Trai11 1809), and G. hacrophynchus Gray, 1846, the animal here noted is referable to the latter. However, some authors are inclined to believe that of upwards of a score of other nominal species one or more may be valid, and it is clear that, in spite of some recent useful preparatory work, the taxonomy of the genus at present remains uncertain, particularly in respect of species and/or subspecies occurring in the southern hemisphere.

The second stranding, that of the false kifler whale (Psendorea crassidens) (plate 2), reported in the daily newspapers of 12.6.1974, was of 170-172 false killer whales on Black River Beach, north western Tasmania, near Stanley. The anima1s probably came ashore the previous day. One of us (E.O.G.S.), with others, visited the 
TABLE 1

Measurements $(\mathrm{cm})$ of a specimen of GLobicephala $\mathrm{ef}$. macrorhynchus stranded at Greens Beach and 9 specimens of Pseudorca crassidens stranded at Black River Beach, near Stanley. The index numbers and dimensions are after Norris (1962). (In the field sma11 dimensions of Pseudorca measured in $\mathrm{cm}$ - eye, mm - larger dimensions to nearest inch).

\begin{tabular}{|c|c|c|c|c|c|c|c|c|c|c|c|}
\hline Ind ex & Feature & Pilot & & & & False & Kill & & & & \\
\hline No. & & $q$ & $\delta$ & 8 & $d$ & 8 & 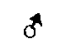 & $d$ & $\stackrel{p}{+}$ & $\stackrel{9}{+}$ & $\stackrel{0}{+}$ \\
\hline 1 & Length to fluke notch & 344 & 236 & 244 & 302 & 381 & 467 & 480 & 384 & 401 & 404 \\
\hline 2 & Length to mid-eye & 35 & 23 & 32 & 34 & 40 & 40 & 42 & 36 & 30 & 30 \\
\hline 4 & Length to gape & 23 & 31 & 29 & 31 & 36 & 32 & 33 & 31 & 33 & 31 \\
\hline 7 & Gape to centre of eye & 10 & 50 & 46 & 53 & 70 & 65 & 70 & 70 & 67 & 68 \\
\hline 9 & $\begin{array}{l}\text { Length of head to } \\
\text { blowhole }\end{array}$ & 35 & 22 & 28 & 39 & 45 & 49 & 49 & 42 & 43 & 43 \\
\hline 10 & Length to pectoral & - & 44 & 52 & 57 & 66 & 76 & 74 & 53 & 57 & 58 \\
\hline 11 & $\begin{array}{l}\text { Length to tip of } \\
\text { dorsal fin }\end{array}$ & 165 & 127 & 133 & 163 & 196 & 239 & 252 & 194 & 192 & 191 \\
\hline 13 & $\begin{array}{l}\text { Length to midpoint of } \\
\text { genital slit }\end{array}$ & - & 140 & 136 & 181 & 218 & 249 & 249 & 239 & 259 & 244 \\
\hline 22 & $\begin{array}{l}\text { Max. girth at dorsal } \\
\text { origin }\end{array}$ & - & 132 & 137 & 165 & 208 & 257 & 239 & 224 & 239 & 220 \\
\hline 24 & Diameter of eye & 2.5 & 3.0 & 2.7 & 2.3 & 3.2 & 3.6 & 3.3 & 2.7 & 3.1 & 3.1 \\
\hline 26 & $\begin{array}{l}\text { Length of genital } \\
\text { slit }\end{array}$ & 26 & 10 & 7 & 11 & 13 & 13 & 30 & 2 & 2 & 3 \\
\hline 27 & Width of blowhole & 7 & - & 40 & - & - & - & - & - & 45 & - \\
\hline 29 & $\begin{array}{l}\text { Length of pectoral, } \\
\text { anterior }\end{array}$ & 52 & 31 & 36 & 43 & 56 & 58 & 70 & 45 & 54 & 56 \\
\hline 30 & $\begin{array}{l}\text { Length of pectoral, } \\
\text { posterior }\end{array}$ & 50 & 29 & 34 & 41 & 54 & 56 & 68 & 43 & 52 & 54 \\
\hline 31 & Width of pectoral & 16 & 11 & 13 & 14 & 19 & 23 & 24 & 17 & 19 & 20 \\
\hline 31 & Height of dorsal fin & 26 & 15 & 23 & 23 & 32 & 40 & 38 & 30 & 32 & 31 \\
\hline 33 & $\begin{array}{l}\text { Length of base of } \\
\text { dorsal fin }\end{array}$ & 51 & 41 & 61 & 69 & 89 & 96 & 102 & 66 & 81 & 78 \\
\hline 34 & Width of flukes & 87 & 53 & 64 & 66 & 86 & 117 & 116 & 86 & 94 & 97 \\
\hline & Dental complement & $\frac{9}{7}$ & $\begin{array}{l}\text { just } \\
\text { erupt- } \\
\text { ing }\end{array}$ & - & $\frac{11}{10}$ & $\frac{7}{9}$ & - & $\frac{9}{10}$ & $\frac{8}{9}$ & - & $\frac{8}{11}$ \\
\hline
\end{tabular}


E.0.G. Scott \& R.H. Green

site on 13-14.6.1974, and, under difficult conditions, collected some data before the animals were buried on the beach.

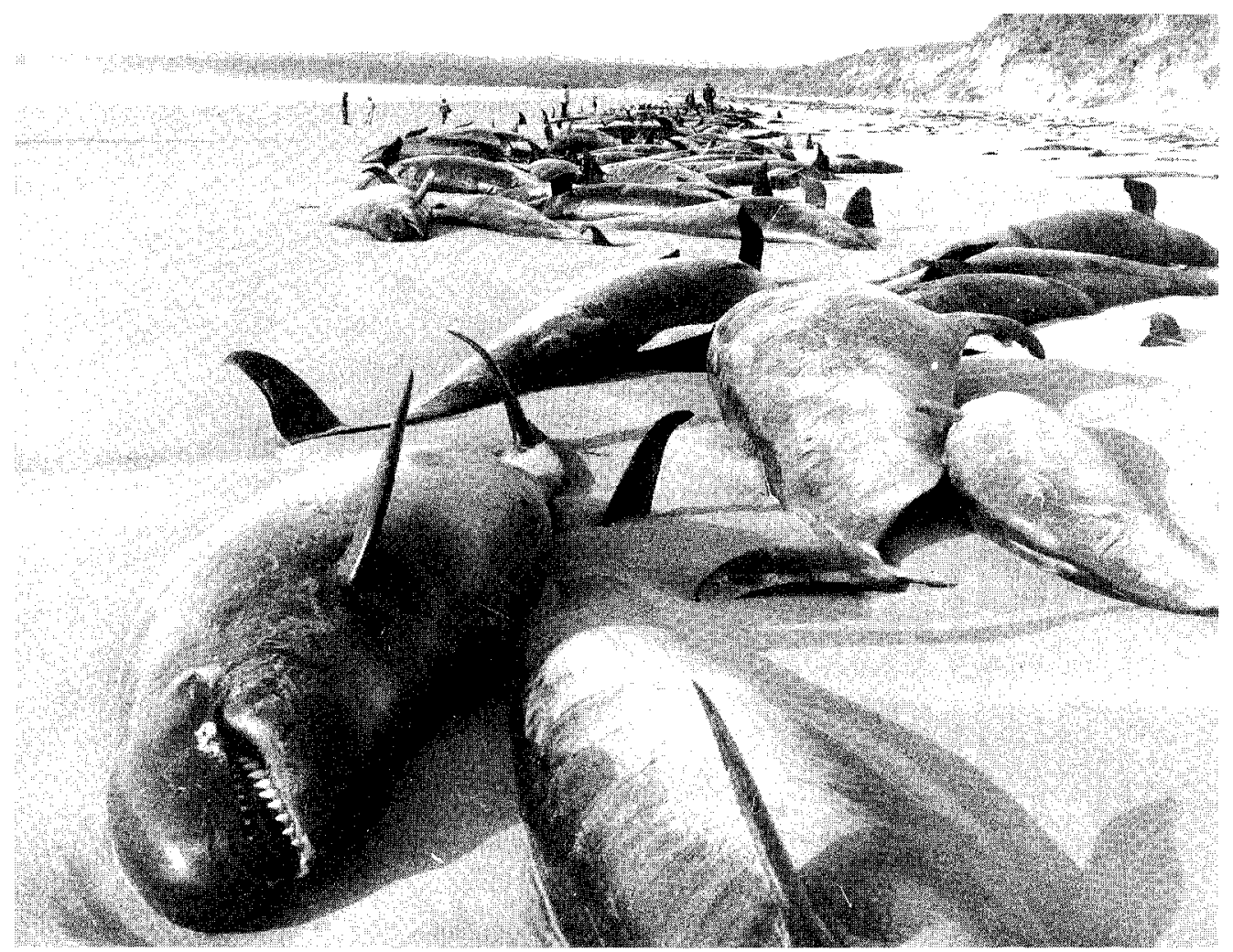

PLATE 2. - False killer whales stranded at Black River Beach, June 1974. Most of the main mass, looking east. Photo: The Advocate.

They were in two groups, the main mass extending over about $100 \mathrm{~m}$, with a smaller compact group of nine lying some $400 \mathrm{~m}$ westward. When seen most were half buried in the sand at or near high tide mark, their orientation haphazard.

The colour was wholly and uniformly black, save that in some individuals a subelliptical whitish or pearly area embraced the umbilicus, extending several centimetres in advance of it and beyond it. As table 1 shows, the range of the dental complement was 7-11 in both the upper and lower jaw.

Length to caudal notch was recorded for 62 individuals, of which 34 were males, 20 females, sex determination being impracticable in 8 (table 2). Eighteen dimensions were noted for each of 6 males and 3 females (table 1). In October 26 females washed out from the mass grave were measured by one of us (R.H.G.): it is possible this series (table 3 ) included some animals measured in June.

Tests of the significance of the difference from the male mean of June, October, pooled female means yield $t=2.898,1.733,2.939$, respectively, the first and third being highly statistically significant ( $P$ better than 0.01 ), the second not being formally significant $\left(\begin{array}{lll}P & 0.1\end{array}\right)$. The length distributions are tolerably symmetrical, the 
number of entries within one standard deviation on either side of the mean (expected values with normal distribution in parentheses) being males 24 (23), June females 15 (14), October females 20 (18) pooled females 34 (31).

TABLE 2

Length to caudal notch (cm) of 62 individuals (34 males, 20 females, 8 unsexed) of Pseudorca crassidens, Black River Beach, near Stanley, measured June 1974; arranged in ascending order of magnitude (measurements in field to nearest inch).

Males

$\begin{array}{llll}236 & 376 & 432 & 488 \\ 267 & 381 & 467 & 488 \\ 267 & 391 & 467 & 488 \\ 302 & 396 & 467 & 493 \\ 302 & 396 & 470 & 498 \\ 322 & 396 & 474 & 518 \\ 343 & 401 & 479 & 523 \\ 395 & 404 & 480 & - \\ 371 & 411 & 480 & -\end{array}$

Females

Sex?

$\begin{array}{ccccc}488 & 234 & 379 & 404 & 137 \\ 488 & 254 & 383 & 409 & 257 \\ 488 & 279 & 383 & - & 325 \\ 493 & 284 & 384 & - & 368 \\ 498 & 312 & 389 & - & 371 \\ 518 & 335 & 389 & - & 396 \\ 523 & 348 & 396 & - & 396 \\ - & 356 & 401 & - & 411 \\ - & 373 & 401 & - & -\end{array}$

It was not feasible to undertake any internal examination. A search was made for barnacles and other ectoparasites, but none were seen. One very small individual, $137 \mathrm{~cm}$ in length, probably not neonatal, was badly eaten by birds. On the morning of the second day a flock of about a dozen ravens, Comus tasmanica Mathews, 1912, was flushed from the nine separate whales, which now appeared whitish, almost the whole of the skin having been stripped off. After an animal has been on the beach for a day or so, the integument can be peeled off in large pieces resembling sheets of black plastic.

The third stranding was brought to the notice of one of us (E.O.G.S.) on 18.6.1974. It took place on the beach and adjacent flats on the west side of Perkins Island, about $10 \mathrm{~km}$ north west of Smithton, approximate1y $20 \mathrm{~km}$ westward from the stranding a week earlier. Mr Jeff Findlay, Health Inspector, Circular Head Municipality, Smithton, reported 43 whales were involved. They appeared to be of the same species as was stranded on Black River Beach, and were thought to have come ashore on the night of 14.6.1974. In view of the isolated character of the site, no attempt was made by the local authority to dispose of the carcases. Perkins Island was the site of a notable stranding in February 1911 (Lillie 1915, Scott 1942a) of a school of 38 individuals (al1, or al1 but one, males) of the sperm whale, Physeter catodon Linne, 1758.

The site of the Black River Beach stranding was revisited by one of us (R.H.G.) on 23.10.1974, when it was discovered that about 70 of the whales, buried there the previous June, had been washed from the sand and were scattered for about three miles $(5 \mathrm{~km})$ along the beach above high tide. With the assistance of $\mathrm{Mr}$ Terence Cashion, Queen Victoria Museum, and Sgt A. Archer, Smithton Police, five heads were taken for skulls and further measurements and other data collected (table 3). Though over four months had elapsed since these whales had died decomposition was only slight, being most pronounced around the mouth. Sexing was a simple matter, males being readily recognisable by the prominently protruding penis. The abdomen of 26 females was opened in an endeavour to assess breeding condition. Four animals were found to be each carrying a single foetus, three being males and one a female. Two foetuses were partly protmuding from the genital slit, possibly because of abnormal pressures. 
E.0.G. Scott \& R.H. Green

Three were in a head-first position and one was in a breech-birth position. The condition of the uterus in another 14 suggested recent parturition. Eight appeared to have not been pregnant in the present season (table 3). The head of one foetus has been preserved in formalin. Tooth wear in females was not as great as in the largest males, in some of which teeth were reduced to about half length.

TABLE 3

Length to caudal notch, apparent breeding condition, and dentition of 26 female Pseudorca crassidens washed from the sand four months after stranding at B1ack River Beach in June 1974. Individuals may or may not be different from those 1 isted in tables 1 and 2 . Some comments on tooth wear are given.

\begin{tabular}{|c|c|c|}
\hline Length $(\mathrm{cm})$ & Breeding condition & Teeth \\
\hline 277 & empty & subadult \\
\hline 293 & empty & subadult \\
\hline 296 & empty & subadult \\
\hline 337 & empty & not worn (skul1 kept) \\
\hline 349 & post partum & not worn \\
\hline 360 & male foetus $(134 \mathrm{~cm})$ & - \\
\hline 361 & post partum & - \\
\hline 367 & female foetus $(122 \mathrm{~cm})$ & not worn (skul1 kept) \\
\hline 368 & empty & - \\
\hline 380 & post partum & not worn \\
\hline 380 & male foetus $(140 \mathrm{~cm})$ & not worn \\
\hline 385 & empty & slight1y worn \\
\hline 386 & empty & - \\
\hline 390 & post partum & - \\
\hline 395 & post partum & - \\
\hline 396 & post partum & - \\
\hline 400 & empty & - \\
\hline 405 & post partum & - \\
\hline 405 & male foetus $(163 \mathrm{~cm})$ & slightly worn (skull kept) \\
\hline 406 & post partum & - \\
\hline 406 & post partum & - \\
\hline 411 & post partum & slightly worn \\
\hline 425 & post partum & not worn \\
\hline 428 & post partum & not worn \\
\hline 452 & post partum & not worn \\
\hline 480 & post partum & \\
\hline
\end{tabular}

It is of interest to note that in June 1936 a mass stranding of false killers, involving 90-100 individuals, occurred at Stanley, and the adjacent Walkers Is 1 and, only some $38 \mathrm{~km}$ westward from Black River Beach: measurements of some specimens made 
by one of us (E.O.G.S.) have been recorded by Pearson (1936, 188). Less than a year earlier (October 1935) the same locality had been the site of the coming ashore of a school of about 300 pilot whales (Scott 1942b), regarded by Davies (1960) as representing a southern subspecies Globiocephala melaena edwardii Smith, 1834. Several large schools of this species have since died on Tasmanian coasts. Other local occurrences of Pseudorea crassidens include one individual at Fanny's Bay, near Piper River heads in October 1957, and some 50 animals at Seal Bay, King Island in September 1958.

Tasmania is, indeed, the type locality of the synonymic Orca memidionazis Flower, 1864, described two years after Reinhardt had reported Pseudorca crassidens as living in the North Sea, Owen's original material having been found, sixteen years earlier, subfossil in a Lincolnshire fen, the species at that time being presumed to be extinct. This Society's journal for the 1919 session contains a paper (Scott $\varepsilon$ Lord 1920) on the osteology of a specimen of a false killer stated to have been one of a mixed school (including also Globicephala melaena and Orcinus orca) that came ashore at Adventure Bay last century.

\section{REFERENCES}

Davies, J.L., 1960: The southern form of Pilot whale. J. Mamm., 41, 29-34.

Lillie, D.G., 1915: Cetacea. Brit. Antaret. (Terra Nova) Exped. 1910, Zool., $1(3)$.

Norris, K.S., 1961: Standardised methods of measuring and recording data on the small cetaceans. J. Mamm., 42, 471-476.

Pearson, J., 1936: The Whales $q$ Dolphins of Tasmania Part 1. External characters $\xi$ habits. Pap. Proc. R. Soc. Tasm., 1936 (1935), 163-192, text figs 1-15.

Scott, E.O.G., 1942a: Records of Tasmanian Cetacea: No. 1. Notes on various strandings at and near Stanley, north-western Tasmania. Rec. Queen Vict. Mus., $1(1), 27-49$, p1s VIII-IX.

, 1942b: Records of Tasmanian Cetacea: No. 2. A large school of the Pilot Whale, Globicephalus melas (Traill, 1809), stranded at Stanley, northwestern Tasmania, in October, 1935. Rec. Queen Vict. Mus. 1(2), 1-34, pls I-XI.

Scott, H.H. and Lord, C.E., 1920: Studies of Tasmanian Cetacea. Part II. Pap. Proc. R. Soc. Tasm., (1919), 1-17, p1s I-IX.

Van Bree, P.J.H., 1971: On GlobicephaZa sieboldii Gray, 1846, and other species of pilot Whales (Notes on Cetacea, Delphinoidea III). Beaufortia, 19(249), 79-87, text figs $1-3$. 